\title{
Influence of elevated carbon dioxide concentrations on methane emission and its associated soil microflora in rice ecosystem
}

\author{
S. K. Rajkishore* \\ Department of Environmental Sciences, Tamil Nadu Agricultural University, Coimbatore \\ - 641003 (Tamil Nadu), India \\ M. Maheswari \\ Department of Environmental Sciences, Tamil Nadu Agricultural University, Coimbatore \\ - 641003 (Tamil Nadu), India

\section{K. S. Subramanian} \\ Director of Research, Tamil Nadu Agricultural University, Coimbatore - 641003 (Tamil Nadu), \\ India \\ R. Prabhu \\ School of Post Graduate Studies, Tamil Nadu Agricultural University, Coimbatore - 641003 \\ (Tamil Nadu), India

\section{G. Vanitha} \\ School of Post Graduate Studies, Tamil Nadu Agricultural University, Coimbatore - 641003 \\ (Tamil Nadu), India \\ ${ }^{*}$ Corresponding author. Email: rajkishoresk@gmail.com
}

\section{How to Cite}

Rajkishore, S. K. et al. (2021). Influence of elevated carbon dioxide concentrations on methane emission and its associated soil microflora in rice ecosystem. Journal of Applied and Natural Science, 13 (SI), 26 - 34. https://doi.org/10.31018/jans.v13iSI.2773

\begin{abstract}
The dynamics of methane emission and its associated soil microflora in rice ecosystem as a response to elevated $\mathrm{CO}_{2}$ concentrations were studied in open top chamber (OTC) conditions. The treatments consisted of three levels of $\mathrm{CO}_{2}(396,550$ and 750 $\left.\mu \mathrm{mol} \mathrm{mol}{ }^{-1}\right)$ and three levels of nitrogen $\left(0,150\right.$ and $\left.200 \mathrm{~kg} \mathrm{ha}^{-1}\right)$ and replicated five times in a completely randomized design. The data showed that elevated $\left[\mathrm{CO}_{2}\right]$ significantly $(P \leq 0.01)$ increased the DOC throughout the cropping period with the values ranging from 533 to $722 \mathrm{mg} \mathrm{L}^{-1}$ and 368 to $501 \mathrm{mg} \mathrm{L}^{-1}$ in $\mathrm{C}_{750}$ and $\mathrm{C}_{\mathrm{amb}}$, respectively. Methane emission rates were monitored regularly during the experiment period and it was revealed that elevated $\left[\mathrm{CO}_{2}\right]$ had increased the methane emissions regardless of stages of crop growth. It was observed that methane emissions were significantly higher under $\left[\mathrm{CO}_{2}\right]$ of $750 \mu \mathrm{mol} \mathrm{mol}^{-1}$ by 33 to 54 per cent over the ambient $\left[\mathrm{CO}_{2}\right]$ of $396 \mu \mathrm{mol} \mathrm{mol}{ }^{-1}$. Consistent with the observed increases in methane flux, the enumeration of methanogens showed a significant $(P \leq 0.01)$ increase under elevated $\left[\mathrm{CO}_{2}\right]$ with the population ranging from 5.7 to 20.1 $\times 10^{4} \mathrm{CFU} \mathrm{g}{ }^{-1}$ of dry soil and 5.1 to $16.9 \times 10^{4} \mathrm{CFU} \mathrm{g}{ }^{-1}$ of dry soil under $\mathrm{C}_{750}$ and $\mathrm{C}_{\mathrm{amb}}$ concentrations, respectively. Interestingly, even though higher methanotrophs population was recorded under elevated [ $\left.\mathrm{CO}_{2}\right]$, it could not circumvent the methane emission. Overall, the results of OTC studies suggest that methane mitigation strategies need to be explored for the future high $\mathrm{CO}_{2}$ environments.
\end{abstract}

Keywords: Elevated $\mathrm{CO}_{2}$, Methane, Methanogens, Methanotrophs, Nitrogen

\section{INTRODUCTION}

Rice fields are considered important sources of atmospheric methane $\left(\mathrm{CH}_{4}\right)$, contributing about 5-19 per cent of total global $\mathrm{CH}_{4}$ emissions to the atmosphere (Intergovernmental Panel on Climate Change , 2018). Methane is the potent greenhouse gas next to carbon dioxide, which is 25 times greater in global warming potential than $\mathrm{CO}_{2}$ on a 100-year horizon (Intergovernmental
Panel on Climate Change , 2013). Projections to the end of this century suggest that atmospheric $\left[\mathrm{CO}_{2}\right]$ will top $700 \mathrm{ppm}$ or more (Intergovernmental Panel on Climate Change , 2018). Photosynthesis, a major process of sequestration and turnover of the total carbon on the planet is strongly influenced by the elevated atmospheric carbon dioxide concentrations. Crops sense and respond directly to rising $\left[\mathrm{CO}_{2}\right]$ through photosynthesis and stomatal conductance and there is a 
need to assess the likely influence of changing atmospheric carbon dioxide concentrations on methane emission and its associated microflora. The amount of $\mathrm{CH}_{4}$ emitted from rice fields to the atmosphere is the balance of two opposite processes, i.e., $\mathrm{CH}_{4}$ production and oxidation in the soil. In the global $\mathrm{CH}_{4}$ cycle, a substantial amount of $\mathrm{CH}_{4}$ is consumed by biological processes. The only known biological sink for atmospheric $\mathrm{CH}_{4}$ is its oxidation in aerobic soils by methanotrophs or methane-oxidizing bacteria (MOB), which can contribute up to 15 per cent to the total global $\mathrm{CH}_{4}$ destruction (Singh, 2011).

With this background, experiments were conducted by employing carbon dioxide enrichment facility to understand the response of elevated carbon dioxide concentrations on methane emission and its associated biological activities, especially methanogens and methanotrophs.

\section{MATERIALS AND METHODS}

\section{Open top chambers (OTCs)}

The influence of elevated levels of $\mathrm{CO}_{2}$ viz., $550 \mu \mathrm{mol} \mathrm{mol}$ ${ }^{-1} \mathrm{CO}_{2}$ and $750 \mu \mathrm{mol} \mathrm{mol}{ }^{-1} \mathrm{CO}_{2}$ on rice crops on methane emission were investigated by employing Open Top Chambers with a dimension of $3 \times 3 \times 3 \mathrm{~m}$.

\section{Pot experiment}

The soil used was sandy clay which belongs to Noyyal series and classified taxonomically as Typic Ustochrept according to USDA classification,1999. The soil was slightly alkaline $(\mathrm{pH}=8.21)$ with low soluble salts $(\mathrm{EC}=$ 0.35). The soil was high in organic carbon content $(6.78$ $\mathrm{g} \mathrm{kg}^{-1}$ ), low in available nitrogen (110.3 $\mathrm{mg} \mathrm{kg}^{-1}$ ), medium in available phosphorus and potassium $\left(6.8 \mathrm{mg} \mathrm{kg}^{-}\right.$ ${ }^{1}$ and $118.0 \mathrm{mg} \mathrm{kg}^{-1}$ ), respectively. Seven kilograms of soil transferred into a syntex pot was used in this study. The FYM at the recommended dose of $12.5 \mathrm{t} \mathrm{ha}^{-1}$ (41.6 $\mathrm{g} \mathrm{pot}^{-1}$ ) and NPK at 150:50:60 kg ha ${ }^{-1}(500,166.6,200$ mg NPK pot ${ }^{-1}$ ) were applied in the form of urea, single super phosphate and muriate of potash, respectively. Zinc sulphate at rate of $25 \mathrm{~kg} \mathrm{ha}^{-1}\left(83.3 \mathrm{mg} \mathrm{pot}^{-1}\right)$ was applied and was thoroughly mixed with the soil. The $\mathrm{N}$ and $K$ was applied in four splits and $P$ was applied basally before transplanting. Rice crop was treated with three different levels of nitrogen viz., 0, 150, $200 \mathrm{~kg} \mathrm{~N}$ $\mathrm{ha}^{-1}$ and the $\mathrm{N}$ was applied in four splits on soil weight basis. Nursery was raised in the wetland farm and 14 days old paddy (ADT 45) seedlings were transplanted into the pots. After establishment, two healthy seedlings were allowed to grow in each pot. Twenty five days old rice crop was subjected to different $\mathrm{CO}_{2}$ atmospheric conditions. The pots were maintained under flooded conditions (cyclic submergence) throughout the crop period.

\author{
Treatments \\ Design: Factorial Competely Randomized Design \\ (FCRD) \\ Replications: Five \\ Factor 1: \\ $\mathrm{C}_{\mathrm{amb}}$ - Ambient $\mathrm{CO}_{2}$ concentration $\left(396 \mu \mathrm{mol} \mathrm{mol}^{-1}\right.$ \\ $\mathrm{CO}_{2}$ ) \\ $\mathrm{C}_{550}-550 \mu \mathrm{mol} \mathrm{mol}{ }^{-1} \mathrm{CO}_{2}$ \\ $\mathrm{C}_{750}-750 \mu \mathrm{mol} \mathrm{mol}{ }^{-1} \mathrm{CO}_{2}$
}

Factor 2:

$\mathrm{N}_{0} \quad-0 \mathrm{~kg} \mathrm{~N} \mathrm{ha}{ }^{-1}$

$\mathrm{N}_{100}-150 \mathrm{~kg} \mathrm{~N} \mathrm{ha}^{-1}$

$\mathrm{N}_{200}-200 \mathrm{~kg} \mathrm{~N} \mathrm{ha}^{-1}$

\section{Estimation of methane flux}

Gas samples were collected from the pots using static closed chamber technique and the gas chambers (250 $\mathrm{mm}$ diameter and $890 \mathrm{~mm}$ height) were fabricated in such a way that it fits the pot. The other specifications and components are similar to the chambers used for field measurements. Gas samples were collected at active tillering, flowering and harvest using tedlar bags and the protocol was followed for collection and estimation were carried out as per the standard procedure (Rajkishore et al., 2013).

\section{Redox potential}

Measurements for redox potential were done with each set of $\mathrm{CH}_{4}$ flux measurement. The redox potential (Eh) of the field soil was measured by inserting a combined waterproof ORP/ redox meter (Eutech Instruments, USA) to the soil and measuring the potential difference in $\mathrm{mV}$ (Satpathy, 1997). The Eh of soil was measured (rhizosphere to bulk soil interface) in the morning and afternoon at different points near the flux measurement setup and averaged for the day.

\section{Dissolved organic carbon (DOC)}

Equilibrated soil solution samples were collected by zero tension sampling using soil water samplers (Tiensing et al., 2001). The DOC was estimated by adopting the protocol of Nelson and Sommers (1996) with a slight modification as described by $\mathrm{Lu}$ et al. (2000). $2 \mathrm{~mL}$ of the soil solution was mixed with $3.0 \mathrm{~mL}$ of deionized water, $5.0 \mathrm{~mL}$ of $0.0175 \mathrm{M} \mathrm{K}_{2} \mathrm{Cr}_{2} \mathrm{O}_{7}, 10.0$ $\mathrm{mL}$ of $98 \% \mathrm{H}_{2} \mathrm{SO}_{4}$, and $5.0 \mathrm{~mL}$ of $88 \% \mathrm{H}_{3} \mathrm{PO}_{4}$ in a tube and digested for $30 \mathrm{~min}$ at $150^{\circ} \mathrm{C}$. Upon cooling, the solutions were transferred to $150 \mathrm{~mL}$ Erlenmeyer flasks and titrated with $0.005 \mathrm{M} \mathrm{Fe}\left(\mathrm{NH}_{4}\right)_{2}\left(\mathrm{SO}_{4}\right)_{2} .6$ $\mathrm{H}_{2} \mathrm{O}$ in $0.4 \mathrm{M} \mathrm{H}_{2} \mathrm{SO}_{4}$ solution and sucrose was used as a standard.

\section{Methanotrophs}

Nine $\mathrm{ml}$ of phosphate buffer solution were taken in test tubes representing up to $10^{-6}$ dilution. Then the tubes 
were sterilized in autoclave at $15 \mathrm{psi}$ for 20 minutes. One gram of soil sample was taken and serially diluted. Dilutions of $10^{-3}$ were used for plating. Pour plate technique was performed using Noble Agar Medium and the plates were incubate in the Macintosh jar assembly (Plate 1) with provisions for attaching a bladder containing methane. Methane was provided as the carbon source for the growth of methanotrophs in the chamber and the plates were incubated for 7 to 15 days. Methane gas was replenished once in two days through the bladder. After fifteen days of incubation, the plates were removed, and the o-dianisidine dye test was performed to assess the methanotrophs activities in the presence of naphthalene crystals. Few naphthalene crystals were sprinkled on the plate lid and stored inverted for 15 minutes. Then the plates were opened and freshly prepared o-dianisidine (tetrazotized; zinc chloride) was sprayed and incubated for 15 minutes in the presence of the dye. Methanotrophs exhibits methane mono oxygenase (MMO) activity and hence, napthol was produced and purple red colour colonies were observed. Methanotrophs colonies (Purple red) colonies were counted and expressed as CFU g ${ }^{-1}$ of dry soil.

\section{Methanogens}

Methanogens were enumerated by adopting the roll tube technique (Hungate, 1957). Soil samples were collected at active tillering, panicle initiation, flowering and harvest stages and enumerated for the population of anaerobic micro-flora. The samples were collected at the lower horizon (10 cm depth) under anaerobic conditions (Ramasamy et al., 1992). The population of methanogens was estimated by using Mah's medium (Mah, 1980). The colonies were identified by their bluish fluorescence under UV light.

\section{Statistical analysis}

The data were statistically analyzed, as suggested by Gomez and Gomez (1984). Wherever the treatment differences were found significant, the critical difference (CD) were worked out at the 5 per cent level of significance with mean separation by least significant difference and denoted by the symbol * (** for $1 \%)$. Treatment differences that were not significant were denoted as 'NS'.

\section{RESULTS AND DISCUSSION}

\section{Redox potential}

Redox potential remained unaltered throughout the growth phase of rice crop regardless of $\mathrm{CO}_{2}$ concentrations or nitrogen levels. In general, the redox potential ranged between $-276 \mathrm{mV}$ and $-281 \mathrm{mV}$ and the values were non-significant. The interaction effect was nonsignificant.

\section{Dissolved organic carbon (DOC)}

DOC was significantly highest under elevated levels of $\mathrm{CO}_{2}$ (Table 1). The highest $\mathrm{DOC}$ was observed under $\mathrm{C}_{750}$ levels and the lowest under $\mathrm{C}_{\mathrm{amb}}$ (ambient) conditions. DOC ranged from 533 to $722 \mathrm{mg} \mathrm{L}^{-1}$ and 368 to $501 \mathrm{mg} \mathrm{L}^{-1}$ in $\mathrm{C}_{750}$ and $\mathrm{C}_{\mathrm{amb}}$, respectively.

Incremental levels of nitrogen addition significantly increased the DOC regardless of the stages of measurements. Highest DOC contents were recorded in $\mathrm{N}_{200}$ and the mean values were 534,621 and $507 \mathrm{mg} \mathrm{L}^{-1}$ at tillering, flowering and harvest stages, respectively. Control $\left(\mathrm{N}_{0}\right)$ registered the lowest DOC contents and the mean values are 455,528 and $436 \mathrm{mg} \mathrm{L}^{-1}$ at tillering, flowering and harvest stages, respectively. Among the stages, flowering recorded the highest DOC contents and lowest at the harvest stage. The interaction effect was non-significant.

Our results revealed that the elevated $\left[\mathrm{CO}_{2}\right]$ significantly increased the DOC throughout the cropping period. Enhanced photosynthesis and plant growth under elevated $\left[\mathrm{CO}_{2}\right]$ had led to increased $\mathrm{C}$ input to the soil (including cortical cell sloughing, root exudation and mortality) (Ineson et al., 1996; Cheng and Johnson, 1998). As soil microorganisms are often $C$ limited (Anderson and Domsch, 1986; Smith and Paul, 1990), more $\mathrm{C}$ input will directly contribute for increased soil microbial biomass and activities. Moreover, in submerged rice soils enhanced algal growth in response to $\mathrm{CO}_{2}$ enrichment was reported to increase microbial biomass of the surface soil (Inubushi et al., 1999; Inubushi et al., 2011).

Increasing atmospheric $\left[\mathrm{CO}_{2}\right]$ is unlikely to directly influence soil microorganisms because $\mathrm{CO}_{2}$ concentrations in soils are already 10-50 times higher than in the atmosphere (Lamborg, 1983; Schortemeyer et al., 1996), even though it usually stimulates plant (especially $\mathrm{C}_{3}$ plant) productivity due to higher net carbon assimilation (Kimball et al., 1993). Nevertheless, elevated atmospheric $\left[\mathrm{CO}_{2}\right]$ may indirectly affect soil microbial populations (Montealegre et al., 2002; Wang et al., 2018), since root biomass, total rhizodeposition, and chemical composition of plant tissues and root exudates probably change when atmospheric $\mathrm{CO}_{2}$ is enriched (Rogers et al., 1994; Schortemeyer et al., 1996; Cai et al., 2016). Our results are in conformity with Li et al. (2004) and Wang et al. (2018), who reported that DOC had a positive relationship with elevated $\left[\mathrm{CO}_{2}\right]$. Nitrogen fertilization significantly increased DOC irrespective of the $\left[\mathrm{CO}_{2}\right]$ and this is attributed to the fact that addition of nitrogen favours increased plant biomass and in turn it contributes for more root exudates which serves as a source of energy for soil microbial population. On the other hand, low $\mathrm{N}$ supplement limited the enhancement of root growth by elevated $\left[\mathrm{CO}_{2}\right]$, leading consequently to the diminished response of $\mathrm{DOC}$ to $\mathrm{CO}_{2}$ enrichment (Li et al., 2004). According to Cardon et al. (2001), the 
Rajkishore, S. K. et al. / J. Appl. \& Nat. Sci. 13 (SI), 26 - 34 (2021)

influence of elevated $\mathrm{CO}_{2}$ on soil microbial population is limited the microbial utilization of $\mathrm{C}$ compounds (van linked to the nutrient status of the soil. Under nitrogen limited conditions, effects of elevated $\mathrm{CO}_{2}$ on plants were generally found to be much smaller (Korner et al., 1997). Besides, it is also suggested that poor $\mathrm{N}$ supply

Veen et al., 1991).

\section{Methanogens}

The present study on the mechanisms associated with

Table 1. Effect of elevated $\mathrm{CO}_{2}$ and nitrogen levels on dissolved organic carbon (DOC).

\begin{tabular}{|c|c|c|c|c|c|c|c|}
\hline \multirow{2}{*}{\multicolumn{2}{|c|}{ Treatments }} & \multicolumn{6}{|c|}{ DOC $\left(\mathrm{mg} \mathrm{L}^{-1}\right)$} \\
\hline & & \multicolumn{2}{|c|}{ Tillering } & \multicolumn{2}{|c|}{ Flowering } & \multicolumn{2}{|c|}{ Harvest } \\
\hline \multirow{4}{*}{$\mathrm{C}_{\mathrm{amb}}$} & $\mathrm{N}_{0}$ & 368 & & 427 & & 350 & \\
\hline & $N_{150}$ & 418 & & 485 & & 397 & \\
\hline & $\mathrm{N}_{200}$ & 430 & & 501 & & 409 & \\
\hline & $\mathrm{N}_{0}$ & 464 & & 538 & & 440 & \\
\hline \multirow{2}{*}{$\mathrm{C}_{550}$} & $N_{150}$ & 529 & & 614 & & 508 & \\
\hline & $\mathrm{N}_{200}$ & 548 & & 639 & & 523 & \\
\hline \multirow{3}{*}{$\mathrm{C}_{750}$} & $\mathrm{~N}_{0}$ & 533 & & 618 & & 517 & \\
\hline & $N_{150}$ & 607 & & 703 & & 573 & \\
\hline & $\mathrm{N}_{200}$ & 624 & & 722 & & 590 & \\
\hline \multirow{7}{*}{ Mean } & $\mathrm{C}_{\mathrm{amb}}$ & 405 & & 471 & & 385 & \\
\hline & $\mathrm{C}_{550}$ & 514 & & 597 & & 490 & \\
\hline & $\mathrm{C}_{750}$ & 588 & & 681 & & 560 & \\
\hline & $\mathrm{N}_{0}$ & 455 & & 528 & & 436 & \\
\hline & $N_{150}$ & 518 & & 601 & & 493 & \\
\hline & $\mathrm{N}_{200}$ & 534 & & 621 & & 507 & \\
\hline & & SEd & $C D$ & SEd & $C D$ & SEd & $C D$ \\
\hline C & & 4.1 & $8.4^{* *}$ & 4.8 & 9.8 & 3.9 & $8.0^{* *}$ \\
\hline $\mathrm{N}$ & & 4.1 & $8.4^{* *}$ & 4.8 & 9.8 & 3.9 & $8.0^{* *}$ \\
\hline $\mathrm{C} \times \mathrm{N}$ & & 7.2 & NS & 8.3 & NS & 6.8 & NS \\
\hline
\end{tabular}

$\mathrm{CO}_{2}$ levels : $\mathrm{C}_{\mathrm{amb}}-396 \mu \mathrm{mol} \mathrm{mol}{ }^{-1} \mathrm{CO}_{2} ; \mathrm{C}_{550}-550 \mu \mathrm{mol} \mathrm{mol}^{-1} \mathrm{CO}_{2} ; \mathrm{C}_{2}-750 \mu \mathrm{mol} \mathrm{mol}^{-1} \mathrm{CO}_{2}$; Nitrogen levels : $\mathrm{N}_{0}-0 \mathrm{~kg} \mathrm{~N}^{-1}$; $\mathrm{N}_{150}-150 \mathrm{~kg} \mathrm{~N} \mathrm{ha}^{-1} ; \mathrm{N}_{200}-200 \mathrm{~kg} \mathrm{~N} \mathrm{ka}^{-1} ;{ }^{*} P \leq 0.05,{ }^{* *} P \leq 0.01$, NS - Non significant

Table 2. Effect of elevated $\mathrm{CO}_{2}$ and nitrogen levels on soil methanogens and methanotrophs population.

\begin{tabular}{|c|c|c|c|c|c|c|c|c|c|c|c|c|c|}
\hline \multicolumn{2}{|c|}{ Treatments } & \multicolumn{6}{|c|}{$\begin{array}{c}\text { Methanogens } \\
\left(\times 10^{4} \mathrm{CFU}^{-1} \text { of dry soil) }\right.\end{array}$} & \multicolumn{6}{|c|}{$\begin{array}{c}\text { Methanotrophs } \\
\left(\times 10^{3} \mathrm{CFU} \mathrm{g}^{-1} \text { of dry soil) }\right.\end{array}$} \\
\hline & & \multicolumn{2}{|l|}{ Tillering } & \multicolumn{2}{|c|}{ Flowering } & \multicolumn{2}{|c|}{ Harvest } & \multicolumn{2}{|c|}{ Tillering } & \multicolumn{2}{|c|}{ Flowering } & \multicolumn{2}{|c|}{ Harvest } \\
\hline \multirow{3}{*}{$\mathrm{C}_{\mathrm{amb}}$} & $\mathrm{N}_{0}$ & 7.60 & & 10.1 & & 5.1 & & 11.4 & & 11.9 & & 12.5 & \\
\hline & $\mathrm{N}_{150}$ & 11.80 & & 15.1 & & 8.2 & & 7.3 & & 7.7 & & 7.9 & \\
\hline & $\mathrm{N}_{200}$ & 13.10 & & 16.9 & & 9.1 & & 6.3 & & 6.5 & & 6.9 & \\
\hline \multirow{3}{*}{$\mathrm{C}_{550}$} & $\mathrm{~N}_{0}$ & 8.10 & & 11.3 & & 5.3 & & 12.4 & & 12.8 & & 13.1 & \\
\hline & $\mathrm{N}_{150}$ & 13.30 & & 17.6 & & 8.6 & & 8.6 & & 9.0 & & 9.5 & \\
\hline & $\mathrm{N}_{200}$ & 14.60 & & 19.5 & & 9.5 & & 6.7 & & 7.2 & & 7.6 & \\
\hline \multirow{3}{*}{$\mathrm{C}_{750}$} & $\mathrm{~N}_{0}$ & 8.90 & & 12.4 & & 5.7 & & 12.9 & & 13.1 & & 13.6 & \\
\hline & $\mathrm{N}_{150}$ & 14.20 & & 18.9 & & 9.0 & & 10.2 & & 10.7 & & 11.0 & \\
\hline & $\mathrm{N}_{200}$ & 14.90 & & 20.1 & & 9.7 & & 7.1 & & 7.9 & & 8.3 & \\
\hline \multirow{7}{*}{ Mean } & $\mathrm{C}_{\mathrm{amb}}$ & 10.8 & & 14.0 & & 7.5 & & 8.4 & & 8.7 & & 9.1 & \\
\hline & $\mathrm{C}_{550}$ & 12.0 & & 16.1 & & 7.8 & & 9.2 & & 9.7 & & 10.1 & \\
\hline & $\mathrm{C}_{750}$ & 12.7 & & 17.1 & & 8.1 & & 10.1 & & 10.5 & & 11.0 & \\
\hline & $\mathrm{N}_{0}$ & 8.2 & & 11.3 & & 5.4 & & 12.2 & & 12.6 & & 13.1 & \\
\hline & $\mathrm{N}_{150}$ & 13.1 & & 17.2 & & 8.6 & & 8.7 & & 9.1 & & 9.5 & \\
\hline & $\mathrm{N}_{200}$ & 14.2 & & 18.8 & & 9.4 & & 6.7 & & 7.2 & & 7.6 & \\
\hline & & SEd & $C D$ & SEd & CD & SEd & CD & SEd & CD & SEd & CD & SEd & $C D$ \\
\hline C & & 0.09 & $0.20^{* *}$ & 0.13 & $0.27^{* *}$ & 0.06 & $0.13^{* *}$ & 0.08 & $0.16^{* *}$ & 0.08 & $0.16^{* *}$ & 0.06 & $0.12^{\star *}$ \\
\hline $\mathrm{N}$ & & 0.09 & $0.20^{* *}$ & 0.13 & $0.27^{* *}$ & 0.06 & $0.13^{* *}$ & 0.08 & $0.16^{* *}$ & 0.08 & $0.16^{\star *}$ & 0.06 & $0.12^{\star *}$ \\
\hline $\mathrm{C} \times \mathrm{N}$ & & 0.17 & $0.35^{*}$ & 0.23 & $0.46^{*}$ & 0.11 & NS & 0.13 & $0.27^{* *}$ & 0.14 & $0.28^{* *}$ & 0.10 & $0.21^{* *}$ \\
\hline
\end{tabular}

$\mathrm{CO}_{2}$ levels : $\mathrm{C}_{\mathrm{amb}}-396 \mu \mathrm{mol} \mathrm{mol}{ }^{-1} \mathrm{CO}_{2} ; \mathrm{C}_{550}-550 \mu \mathrm{mol} \mathrm{mol}^{-1} \mathrm{CO}_{2} ; \quad \mathrm{C}_{2}-750 \mu \mathrm{mol} \mathrm{mol}^{-1} \mathrm{CO}_{2}$; Nitrogen levels : $\mathrm{N}_{0}-0 \mathrm{~kg} \mathrm{~N} \mathrm{ha}^{-1}$; $\mathrm{N}_{150}-150 \mathrm{~kg} \mathrm{~N} \mathrm{ha}^{-1} ; \mathrm{N}_{200}-200 \mathrm{~kg} \mathrm{~N} \mathrm{ha}^{-1} ;{ }^{*} P \leq 0.05,{ }^{* *} P \leq 0.01, \mathrm{NS}-$ Non significant 
Rajkishore, S. K. et al. / J. Appl. \& Nat. Sci. 13 (SI), 26 - 34 (2021)

methane flux under elevated $\left[\mathrm{CO}_{2}\right]$, the population dynamics of methanogens and methanotrophs showed that the Methanogen population was significantly $(P \leq$ $0.05)$ highest under elevated $\mathrm{CO}_{2}$ levels regardless of stages of observation (Table 2). $\mathrm{C}_{750}$ had a significantly highest methanogen population, ranging from 5.7 to $20.1 \times 10^{4} \mathrm{CFU} \mathrm{g}^{-1}$ of dry soil, while the lowest population ranged from 5.1 to $16.9 \times 10^{4} \mathrm{CFU} \mathrm{g}^{-1}$ of dry soil under ambient $\left(\mathrm{C}_{\mathrm{amb}}\right)$ concentration. At flowering, the mean values were $14.0,16.1$ and $17.1 \times 10^{4} \mathrm{CFU} \mathrm{g}^{-1}$ of dry soil under 396, 550 and $750 \mu \mathrm{mol} \mathrm{mol}^{-1} \mathrm{CO}_{2}$ concentrations, respectively. Nitrogen significantly increased the methanogen population irrespective of $\mathrm{CO}_{2}$ levels or stages. The highest methanogen load (9.1 to $20.1 \times 10^{4} \mathrm{CFU} \mathrm{g}^{-1}$ of dry soil) was observed in $\mathrm{N}_{200}$, while the lowest population (5.1 to $12.4 \times 10^{4} \mathrm{CFU} \mathrm{g}{ }^{-1}$ of dry soil) was recorded in $\mathrm{N}_{0}$. Among the stages, flowering registered the highest methanogen population and the lowest at the harvest stage irrespective of $\mathrm{CO}_{2}$ levels. The interaction effect was significant only at tillering and flowering stages.

\section{Methanotrophs}

Elevated $\mathrm{CO}_{2}$ levels significantly increased the soil methanotrophs population irrespective of stages of observation (Table 2). The highest methanotrophs population ranging from 7.1 to $13.6 \times 10^{3} \mathrm{CFU} \mathrm{g}^{-1}$ of dry soil was observed in $\mathrm{C}_{750}$ while the lowest population ranging from 6.3 to $12.5 \times 10^{3} \mathrm{CFU} \mathrm{g}^{-1}$ of dry soil in ambient
$\mathrm{CO}_{2}$ concentration. At harvest, the mean values are 9.1, 10.1 and $11.0 \times 10^{3} \mathrm{CFU} \mathrm{g}^{-1}$ of dry soil under 396 , 550 and $750 \mu \mathrm{mol} \mathrm{mol}{ }^{-1} \mathrm{CO}_{2}$ concentrations, respectively. Incremental levels of nitrogen addition significantly decreased the methanotrophs population regardless of $\mathrm{CO}_{2}$ concentrations or stages of observation. The highest mean values (12.2, 12.6 and $13.1 \times 10^{3}$ CFU g ${ }^{-1}$ of dry soil) were observed in $\mathrm{N}_{0}$, while the lowest population $\left(6.7,7.2\right.$ and $7.6 \times 10^{3} \mathrm{CFU} \mathrm{g}{ }^{-1}$ of dry soil) was recorded in $\mathrm{N}_{200}$ at tillering, flowering and harvest stages, respectively. Among the stages, harvest registered the highest methanotrophs population and the lowest at tillering stage irrespective of $\mathrm{CO}_{2}$ levels. The interaction effect was significant.

Consistent with the observed increases in methane flux, the enumeration of methanogens showed a significant increase under elevated $\left[\mathrm{CO}_{2}\right]$. This positive effect of elevated $\left[\mathrm{CO}_{2}\right]$ may be attributed to stimulated rice above ground and below ground biomasses (Ziska et al., 1998; Liu et al., 2016) which might have provided more carbon substrates for methanogens (Hou et al., 2000; Inubushi et al., 2003; Yue et al., 2003; Yue et al., 2007; Liu et al., 2016; Li et al., 2017). Root exudation accounts for approximately $0.5-5.0$ per cent of net fixed C (Farrar and Jones, 2003) and provides 10 and 50 per cent of the carbon substrate needed for methanogenesis (Seiler et al., 1984). In addition, the cells are sloughed from the cortices of living roots and lysates consisting of polymeric C compounds and enzymes

Table 3. Effect of elevated $\mathrm{CO}_{2}$ and nitrogen levels on methane emission.

\begin{tabular}{|c|c|c|c|c|c|c|c|c|c|}
\hline \multirow{2}{*}{\multicolumn{2}{|c|}{ Treatments }} & \multicolumn{6}{|c|}{ Methane emission $\left(\mathrm{mg} \mathrm{pot}^{-1} \mathrm{~d}^{-1}\right)$} & \multirow{2}{*}{$\begin{array}{l}\text { Average } \\
\text { methane } \\
\text { emission } \\
\left(\mathrm{mg} \mathrm{pot}^{-1} \mathrm{~d}^{-1}\right)\end{array}$} & \multirow{2}{*}{$\begin{array}{l}\text { Total } \\
\text { methane } \\
\text { emission } \\
\left(\text { g pot }^{-1}\right)\end{array}$} \\
\hline & & \multicolumn{2}{|l|}{ Tillering } & \multicolumn{2}{|c|}{ Flowering } & \multicolumn{2}{|c|}{ Harvest } & & \\
\hline & $\mathrm{N}_{0}$ & 1.43 & & 4.13 & & 0.50 & & 2.02 & 0.22 \\
\hline \multirow[t]{3}{*}{$\mathrm{C}_{\mathrm{amb}}$} & $\mathrm{N}_{150}$ & 2.00 & & 5.27 & & 0.66 & & 2.64 & 0.29 \\
\hline & $\mathrm{N}_{200}$ & 2.19 & & 5.54 & & 0.83 & & 2.85 & 0.31 \\
\hline & $\mathrm{N}_{0}$ & 1.79 & & 5.41 & & 0.61 & & 2.60 & 0.29 \\
\hline \multirow[t]{3}{*}{$\mathrm{C}_{550}$} & $\mathrm{~N}_{150}$ & 2.54 & & 6.96 & & 0.80 & & 3.43 & 0.38 \\
\hline & $\mathrm{N}_{200}$ & 2.83 & & 7.38 & & 1.00 & & 3.74 & 0.41 \\
\hline & $\mathrm{N}_{0}$ & 2.04 & & 6.35 & & 0.67 & & 3.02 & 0.33 \\
\hline \multirow[t]{4}{*}{$\mathrm{C}_{750}$} & $\mathrm{~N}_{150}$ & 2.88 & & 8.15 & & 0.87 & & 3.97 & 0.44 \\
\hline & $\mathrm{N}_{200}$ & 3.19 & & 8.52 & & 1.09 & & 4.27 & 0.47 \\
\hline & $\mathrm{C}_{\mathrm{amb}}$ & 1.87 & & 4.98 & & 0.66 & & 2.51 & 0.28 \\
\hline & $\mathrm{C}_{550}$ & 2.39 & & 6.58 & & 0.80 & & 3.26 & 0.36 \\
\hline \multirow{5}{*}{$\begin{array}{l}\text { Mea } \\
n\end{array}$} & $\mathrm{C}_{750}$ & 2.70 & & 7.67 & & 0.88 & & 3.75 & 0.41 \\
\hline & $\mathrm{N}_{0}$ & 1.75 & & 5.30 & & 0.59 & & 2.55 & 0.28 \\
\hline & $\mathrm{N}_{150}$ & 2.47 & & 6.79 & & 0.78 & & 3.35 & 0.37 \\
\hline & $\mathrm{N}_{200}$ & 2.74 & & 7.15 & & 0.98 & & 3.62 & 0.40 \\
\hline & & SEd & CD & SEd & CD & SEd & $C D$ & & \\
\hline \multicolumn{2}{|l|}{ C } & 0.019 & $0.039^{* *}$ & 0.053 & $0.108^{* *}$ & 0.007 & $0.014^{* *}$ & & \\
\hline \multicolumn{2}{|l|}{$\mathrm{N}$} & 0.019 & $0.039^{* *}$ & 0.053 & $0.108^{* *}$ & 0.007 & $0.014^{* *}$ & & \\
\hline \multicolumn{2}{|c|}{$\mathrm{C} \times \mathrm{N}$} & 0.034 & $0.069^{* *}$ & 0.093 & $0.118^{*}$ & 0.012 & $0.024^{*}$ & & \\
\hline
\end{tabular}

$\mathrm{CO}_{2}$ levels : $\mathrm{C}_{\text {amb }}-396 \mu \mathrm{mol} \mathrm{mol}{ }^{-1} \mathrm{CO}_{2} ; \mathrm{C}_{550}-550 \mu \mathrm{mol} \mathrm{mol}^{-1} \mathrm{CO}_{2} ; \mathrm{C}_{2}-750 \mu \mathrm{mol} \mathrm{mol}{ }^{-1} \mathrm{CO}_{2} ;$ Nitrogen levels : $\mathrm{N}_{0}-0 \mathrm{~kg} \mathrm{~N}$ ha $\mathrm{N}_{150}-150 \mathrm{~kg} \mathrm{~N} \mathrm{ha}^{-1} ; \mathrm{N}_{200}-200 \mathrm{~kg} \mathrm{~N} \mathrm{ha}^{-1} ;{ }^{*} P \leq 0.05,{ }^{* *} P \leq 0.01$, NS - Non significant 
enter the rhizosphere, providing further substrate for microorganisms (Farrar et al., 2003). This fact also supports our observations on methanotrophs, which was found to be higher under elevated $\left[\mathrm{CO}_{2}\right]$. Interestingly, the data showed that the highest methanotrophic population was found at the harvest stage and these observations are in accordance with (Yue et al., 2007), who reported enhanced populations of methanotrophs at maturing periods under elevated $\left[\mathrm{CO}_{2}\right]$. This suggests that the availability of $\mathrm{O}_{2}$ and the concentration of $\mathrm{CH}_{4}$ jointly determine the methanotrophic activity (van Bodegom et al., 2001).

\section{Effect of elevated $\mathrm{CO}_{2}$ on methane emissions}

\section{Methane emission rate}

Elevated $\mathrm{CO}_{2}$ levels significantly increased the methane emission rate irrespective of stages of observation (Table 3). $\mathrm{CO}_{2}$ concentration @ $750 \mu \mathrm{mol} \mathrm{mol}{ }^{-1} \mathrm{CO}_{2}$ recorded the highest methane emission rate $(0.67$ to $\left.8.52 \mathrm{mg} \mathrm{pot}^{-1} \mathrm{~d}^{-1}\right)$ while the lowest rate $(0.50$ to $5.54 \mathrm{mg}$ $\operatorname{pot}^{-1} \mathrm{~d}^{-1}$ ) was observed under ambient concentration. The highest mean methane emission values $(2.70,7.67$ and $0.88 \mathrm{mg} \mathrm{pot}^{-1} \mathrm{~d}^{-1}$ ) in $\mathrm{C}_{750}$ and the lowest values $\left(1.87,4.98\right.$ and $\left.0.66 \mathrm{mg} \mathrm{pot}^{-1} \mathrm{~d}^{-1}\right)$ in $\mathrm{C}_{\text {amb }}$ were recorded at tillering, flowering and harvest stages, respectively. $\mathrm{C}_{750}$ increased the methane emission rate by $44.4,54.0$ and 33.3 per cent over $\mathrm{C}_{a m b}$ at tillering, flowering and harvest stages, respectively. Under $\mathrm{C}_{550}$ levels, the methane emission rate increased by $27.8,32.1$ and 21.2 per cent over $\mathrm{C}_{a m b}$ at tillering, flowering and harvest stages, respectively. The methane emission rate increased under $C_{750}$ to the tune of 13.0, 16.6 and 10per cent over $\mathrm{C}_{550}$ at tillering, flowering and harvest stages, respectively.

Addition of nitrogen significantly increased the methane emission rate regardless of $\mathrm{CO}_{2}$ levels or stages of observation. The highest mean values $(2.74,7.15$ and $\left.0.98 \mathrm{mg} \mathrm{pot}^{-1} \mathrm{~d}^{-1}\right)$ and the lowest values (1.75, 5.30 and $0.59 \mathrm{mg} \mathrm{pot}^{-1} \mathrm{~d}^{-1}$ ) were recorded in $\mathrm{N}_{200}$ and $\mathrm{N}_{0}$ at tillering, flowering and harvest stages, respectively. At the flowering stage, the highest methane emission rate was recorded while harvest registered the lowest. The interaction effect was significant.

\section{Average methane emission}

The average methane emissions ranged from 2.02 to $2.85 \mathrm{mg} \mathrm{pot}^{-1} \mathrm{~d}^{-1}, 2.60$ to $3.74 \mathrm{mg} \mathrm{pot}^{-1} \mathrm{~d}^{-1}$ and 3.02 to $4.27 \mathrm{mg} \mathrm{pot}^{-1} \mathrm{~d}^{-1}$ under 396,550 and $750 \mu \mathrm{mol} \mathrm{mol}^{-1}$ $\mathrm{CO}_{2}$, concentrations, respectively (Table 3 ). The mean values are $2.51,3.26$ and $7.75 \mathrm{mg} \mathrm{pot}^{-1} \mathrm{~d}^{-1}$ under $\mathrm{C}_{\mathrm{amb}}, \mathrm{C}_{550}$ and $\mathrm{C}_{750}$ levels, respectively. With respect to nitrogen levels, the mean values are $2.55,3.35$ and $3.62 \mathrm{mg} \mathrm{pot}^{-}$ ${ }^{1} \mathrm{~d}^{-1}$ in $\mathrm{N}_{0}, \mathrm{~N}_{150}$ and $\mathrm{N}_{200}$, respectively.

\section{Total methane emission}

The total methane emission was highest under $750 \mu$ mol mol ${ }^{-1} \mathrm{CO}_{2}$ followed by $550 \mu \mathrm{mol} \mathrm{mol}^{-1} \mathrm{CO}_{2}$ and the lowest under $396 \mu \mathrm{mol} \mathrm{mol}{ }^{-1} \mathrm{CO}_{2}$ concentrations (ambient) (Table 3). Total methane emission ranged from 0.22 to $0.31 \mathrm{~g} \mathrm{pot}^{-1}, 0.29$ to $0.41 \mathrm{~g} \mathrm{pot}^{-1}$ and 0.33 to $0.47 \mathrm{~g} \mathrm{pot}^{-1}$ under $\mathrm{C}_{\mathrm{amb}}, \mathrm{C}_{550}$ and $\mathrm{C}_{750}$ levels, respectively. The highest mean value $\left(0.41 \mathrm{~g} \mathrm{pot}^{-1}\right)$ was observed in $C_{750}$, while the lowest value $\left(0.28 \mathrm{~g} \mathrm{pot}^{-1}\right)$ in $\mathrm{C}_{\mathrm{amb}} . \mathrm{C}_{750}$ increased the total methane emission by 46.4 per cent and 13.9 per cent over the $C_{a m b}$ and $C_{550}$ levels, respectively. The total methane emission increase was to the tune of 28.6 per cent in $\mathrm{C}_{550}$ level over the ambient $\mathrm{CO}_{2}$ concentration.

Total methane emission increased with increasing doses of nitrogen fertilizers. $\mathrm{N}_{200}$ increased the total methane emission by 42.9 per cent and 8.1 per cent over the $N_{0}$ and $N_{150}$ levels, respectively. The total methane emission increase was to the tune of 32.1 per cent in $\mathrm{N}_{150}$ over the control $\left(\mathrm{N}_{0}\right)$.

The data clearly indicated that methane emissions
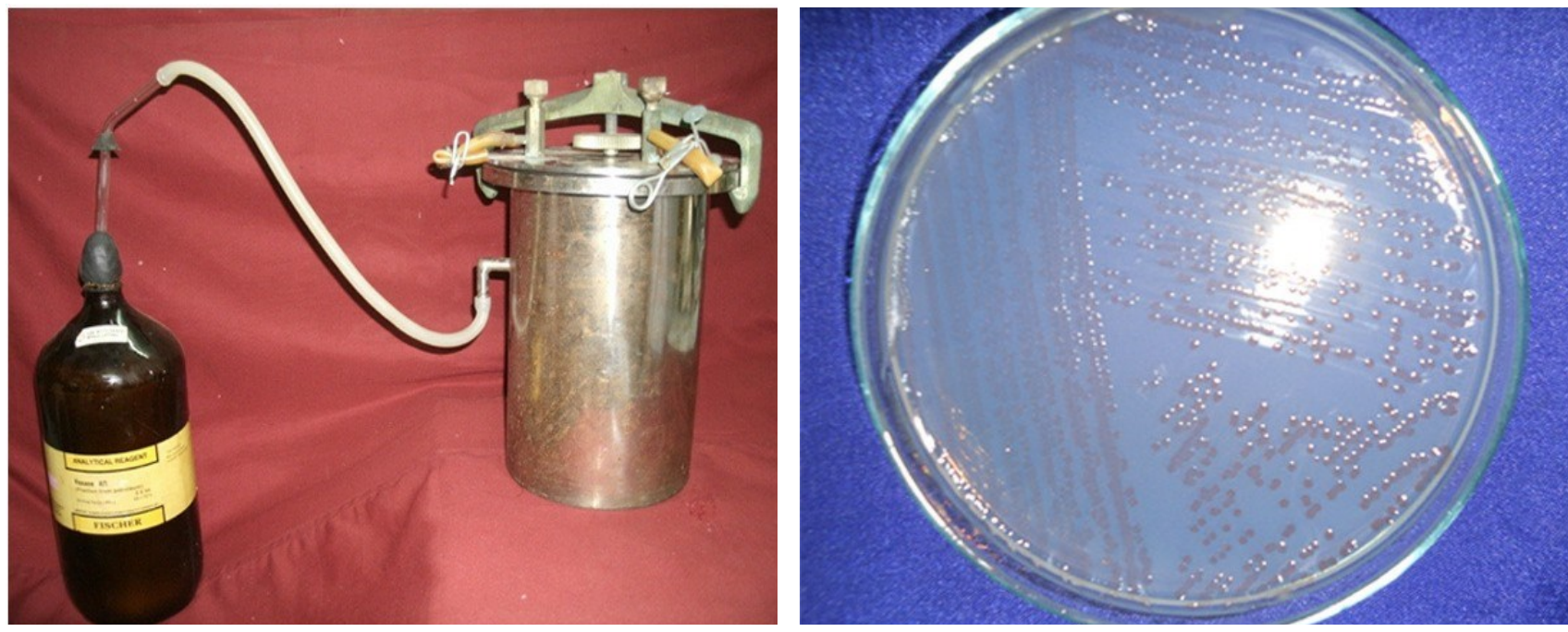

Plate 1. Mcintosh jar assembly and colonies of methanotrophs. 
were significantly higher under $\left[\mathrm{CO}_{2}\right]$ of $750 \mu \mathrm{mol} \mathrm{mol}{ }^{-1}$ by 33 to 54 per cent over the ambient $\left[\mathrm{CO}_{2}\right]$ of 396 $\mu \mathrm{mol} \mathrm{mol}{ }^{-1}$. Our results are in line with ample literature which reported that elevated $\left[\mathrm{CO}_{2}\right]$ enhanced the methane emissions by 49 to 60 per cent @ $650 \mathrm{\mu mol} \mathrm{mol}^{-}$ ${ }^{1}$ (Ziska et al., 1998), 38 to 51 per cent @ $550 \mathrm{\mu mol} \mathrm{mol}^{-1}$ (Inubushi et al., 2003), 58 per cent @ $700 \mathrm{\mu mol} \mathrm{mol}^{-1}$ (Cheng et al., 2006), 26 per cent @ $580 \mu \mathrm{mol} \mathrm{mol}^{-1}$ (Tokida et al., 2010) and 28-120 per cent @ $500 \mu \mathrm{mol}$ $\mathrm{mol}^{-1}$ (Wang et al., 2018) over the ambient $\left[\mathrm{CO}_{2}\right]$. These facts are further supported by a recent metaanalysis report (van Groenigen et al., 2011), indicating that $\left[\mathrm{CO}_{2}\right]$ between 463 to $780 \mu \mathrm{mol}$ mol-1 stimulated $\mathrm{CH} 4$ emissions an average by 43.4 per cent. $\mathrm{CH}_{4}$ is the dominant terminal degradation product of soil organic materials in submerged rice fields (Kruger et al., 2001), therefore, increased $\mathrm{C}$ input to the soil in response to elevated $\left[\mathrm{CO}_{2}\right]$ leads likely to enhanced $\mathrm{CH}_{4}$ production (Ziska et al., 1998; Li et al., 2004; Cai et al., 2016). Moreover, the positive correlations between $\mathrm{CH}_{4}$ emissions and above-ground or root biomass also agree well with the results of previous studies suggesting that greater assimilation of carbon under high $\left[\mathrm{CO}_{2}\right]$ leads to higher rates of rhizo-deposition (root exudation and autolysis products), which is an important source of substrates for $\mathrm{CH}_{4}$ production (Inubushi et al., 2003; Xu et al., 2004; Tokida et al., 2010; Cai et al., 2016; Wang et al., 2018). Further, the positive correlation of DOC with methane emissions also adds strength to our results. Among the different stages of observation, the flowering stage recorded the highest methane flux irrespective of $\left[\mathrm{CO}_{2}\right]$. This period generally corresponds with increased availability of root sloughing or exudates due to peak photosynthetic activity and advanced root senescence and might probably provide more substrate for methanogenesis (Allen et al, 2003; Tokida et al., 2010; Li et al., 2017). The results from the present experiment also demonstrated that nitrogen fertilization increased the methane flux irrespective of $\left[\mathrm{CO}_{2}\right]$. Inference from our observations is in line with Schimel (2000), who have reported that the application of $\mathrm{N}$ fertilizers enhances rice biomass and contributed for enhanced root exudates that favours methane production.

\section{Conclusion}

Elevated $\mathrm{CO}_{2}$ levels favoured methane emission as a result of enhanced carbon assimilation and production of energy rich root exudates that stimulated microbial activities in the soil rhizosphere of rice ecosystem. Consistent with the observed increases in methane flux, the enumeration of methanogens showed a significant $(P \leq 0.01)$ increase under elevated $\left[\mathrm{CO}_{2}\right]$. In addition, the methanotrophs population was also signifi- cantly $(P \leq 0.01)$ highest under elevated $\mathrm{CO}_{2}$ levels regardless of stages of observation. Incremental levels of nitrogen addition significantly increased the methanogens but decreased the methanotrophs population regardless of $\mathrm{CO}_{2}$ concentrations or stages of observation. This study unequivocally demonstrated that even though higher methanotrophs population was recorded under elevated $\left[\mathrm{CO}_{2}\right]$, it could not circumvent the methane emission, thereby showcasing the knowledge gap and suggesting that methane mitigation strategies need to be explored for the future high $\mathrm{CO}_{2}$ environments by duly optimizing the dosage of nitrogenous fertilizer.

\section{Conflict of interest}

The authors declare that they have no conflict of interest.

\section{REFERENCES}

1. Allen, L.H., Stephan, L., Albrecht, W., Colo'n-Guasp, S.A., Covell, J.T., Baker, D., Pan \& Boote, K.J. (2003). Methane emissions of rice increased by elevated carbon dioxide and temperature. J. Environ. Qual., 32, 1978-1991.

2. Anderson, T.H. \& Domsch, K.H. (1986). Carbon link between microbial biomass and soil organic matter. In: Proceedings of the Fourth International Symposium on Microbial Ecology. Eds. F Megusar and M Gantar. Ljubljana, Yugoslavia. pp. 471-476.

3. Cai, C., Yin, X., He, S., Jiang, W., Si, C., Struik, P.C., Luo, W., Li, G., Xie, Y., Xiong, Y. \& Pan, G. (2016). Responses of wheat and rice to factorial combinations of ambient and elevated $\mathrm{CO}_{2}$ and temperature in FACE experiments. Global Change Biol., 22, 856-874.

4. Cardon, Z.G., Hungate, B.A., Cambardella, C.A., Chapin, F.S., Field, C.B., Holland, E.A., \& Mooney, H.A. (2001). Contrasting effects of elevated $\mathrm{CO}_{2}$ on old and new soil carbon pools. Soil Biol. Biochem., 33, 365-373.

5. Cheng, W. \& Johnson, D.W. (1998). Elevated $\mathrm{CO}_{2}$, rhizosphere processes and soil organic matter decomposition. Plant Soil, 202, 167-174.

6. Cheng, W., Yagi, K., Sakai, H. \& Kobayashi, K. (2006). Effects of elevated atmospheric $\mathrm{CO}_{2}$ concentrations on $\mathrm{CH}_{4}$ and $\mathrm{N}_{2} \mathrm{O}$ emission from rice soil: an experiment in controlled-environment chambers. Biogeochemistry, 77, 351-373.

7. Farrar, J., Hawes, M., Jones, D. \& Lindow, S. (2003). How roots control the flux of carbon to the rhizosphere. Ecol., 84, 827-837.

8. Farrar, J.F. \& Jones, D.L. (2003). The control of carbon acquisition by and growth of roots. In: Kroon $\mathrm{H}$ de, Visser EJW. Ed: Root Ecology. Springer, Berlin Heidelberg, New York. pp. 90-124.

9. Gomez, K.A. \& Gomez, A.A. (1984). Statistical Procedures for Agricultural Research. John Wiley and Sons, New Delhi, p.680.

10. Hou, A.X., Chen, G.X., Wang, Z.P., Van Cleemput, O. \& Patrick, W.H. (2000). Methane and nitrous oxide emissions from a rice field in relation to soil redox and microbiological processes. Soil Sci. Soc. Am. J., 64, 2180-2186. 
11. Hungate, R.S. (1957). Microorganisms in the rumen of cattle fed at a constant ration. Can. J. Microbiol., 3, 289311.

12. Ineson, P., Cotrufo, M.F., Bol, R., Harkness, D.D. \& Blum, H. (1996). Quantification of soil carbon inputs under elevated CO2: $\mathrm{C}_{3}$ plants in a $\mathrm{C}_{4}$ soil. Plant Soil., 187, 345-350.

13. Inubushi, K., Cheng, W. \& Chander, K. (1999). Carbon dynamics in submerged soil microcosms as influenced by elevated $\mathrm{CO}_{2}$ and temperature. Soil Sci. Plant Nutr., 45, 863-872.

14. Inubushi, K., Cheng, W., Aonuma, S., Hoque, M.M., Kobayashi, K. \& Miura, S. (2003). Effects of free-air $\mathrm{CO}_{2}$ enrichment (FACE) on $\mathrm{CH}_{4}$ emission from a rice paddy field. Global Change Biol., 9, 1458-1464.

15. Inubushi, K., Cheng, W., Mizuno, T., Lou, Y., Hasegawa T., Sakai, H. \& Kobayashi, K. (2011). Microbial biomass carbon and methane oxidation influenced by rice cultivars and elevated $\mathrm{CO}_{2}$ in a Japanese paddy soil. E. J. Soil Sci., 62, 69-73.

16. Intergovernmental Panel on Climate Change (2013). Climate Change. The Physical Science Basis. Contribution of Working Group I to the Fifth Assessment Report of the Intergovernmental Panel on Climate Change (Eds. T.F. Stocker, D. Qin, G.K. Plattner, M. Tignor, S.K. Allen, J. Boschung, A. Nauels, Y. Xia, V. Bex and P.M. Midgley), Cambridge University Press, Cambridge, United Kingdom and New York, NY, USA, p. 1535.

17. Intergovernmental Panel on Climate Change (2018). Summary for Policymakers. In: Global Warming of $1.5^{\circ} \mathrm{C}$. An IPCC Special Report on the impacts of global warming of $1.5^{\circ} \mathrm{C}$ above pre-industrial levels and related global greenhouse gas emission pathways, in the context of strengthening the global response to the threat of climate change, sustainable development, and efforts to eradicate poverty (Eds. V. Masson-Delmotte, P. Zhai, H.O. Pörtner, D. Roberts, J. Skea, P.R. Shukla, A. Pirani, W. Moufouma-Okia, C. Péan, R. Pidcock, S. Connors, J.B.R. Matthews, Y. Chen, X. Zhou, M.I. Gomis, E. Lonnoy, T. Maycock, M. Tignor and T. Waterfield), In Press.

18. Kimball, B.A., Mauney, J.R., Nakayama, F.S. \&ldso, S.B. (1993). Effects of increasing $\mathrm{CO}_{2}$ on vegetation. Vegetation, 104/105, 65-75.

19. Korner, C., Diemer, M., Schappi, B., Niklaus, P.A. \& Arnone, J.A. (1997). The responses of alpine grassland to four seasons of $\mathrm{CO}_{2}$ enrichment: a synthesis. Acta Oecol., 18, 165-176.

20. Kruger, M., Frenzel, P. \& Conrad, R. (2001). Microbial processes influencing methane emission from rice fields. Global Change Biol., 7, 49-63.

21. Lamborg, M.R. (1983). Microbial effects. In: Lemon, E.R. (Ed.), The Response of Plants to Rising Levels of Atmospheric Carbon Dioxide. Westview Press, Boulder, pp. 131-176.

22. Li, Z., Yagi, K., Sakai, H. \& Kobayashi, K. (2004). Influence of elevated $\mathrm{CO}_{2}$ and nitrogen nutrition on rice plant growth, soil microbial biomass, dissolved organic carbon and dissolved $\mathrm{CH}_{4}$. Plant Soil, 258, 81-90.

23. Li, S., Song, L., Gao, X., Jin, Y., Liu, S., Shen, Q. \& Zou, J. (2017). Microbial abundances predict methane and nitrous oxide fluxes from a windrow composting system. Front. Microbiol., 8, 409.

24. Liu, Y., Liu, X., Cheng, K., Li, L., Zhang, X., Zheng, J.,
Zheng, J. \& Pan, G. (2016). Responses of methanogenic and methanotrophic communities to elevated atmospheric $\mathrm{CO}_{2}$ and temperature in a paddy field. Front. Microbiol., 7 , 1895.

25. Lu, Y., Wassmann, R.H., Neue, U. \& Huang, C. (2000). Dynamics of dissolved organic carbon and methane emissions in a flooded rice soil. Soil Sci. Soc. Am. J., 64, 2011-2017.

26. Mah, R.S. (1980). Isolation and characterization of Methanococcus mazei. Curr. Microbiol., 3, 321-326.

27. Montealegre, C.M., Van Kessel, C., Russelle, M.P. \& Sadowsky, M.J. (2002). Changes in microbial activity and composition in a pasture ecosystem exposed to elevated atmospheric carbon dioxide. Plant Soil, 243, 197-207.

28. Nelson, D.W. \& Sommers, L.E. (1996). Total carbon, organic carbon and organic matter. In: D.L. Sparks (ed.) Methods of soil analysis. Part 3. SSSA Book Ser. 5. SSSA, Madison, WI. pp. 961-1010.

29. Rajkishore, S.K., Doraisamy, P., Subramanian, K.S. \& Maheswari, M. (2013). Methane emission patterns and their associated soil microflora with SRI and conventional systems of rice cultivation in Tamil Nadu, India. Taiwan Water Conservancy, 61(4), 126-134.

30. Ramasamy, K., Kalaichelvan, G. \& Nagamani, B. (1992). Working with anaerobes: methanogens. A Laboratory manual. pp. 94.

31. Rogers, H.H., Runion, G.B. \& Krupa, S.V. (1994). Plant responses to atmospheric $\mathrm{CO}_{2}$ enrichment with emphasis on roots and the rhizosphere. Environ. Pollut., 83, 155189.

32. Satpathy, S.N. (1997). Factors affecting methane emission in tropical rice soil. Ph.D. Thesis, Utkal University, Bhubaneswar.

33. Schimel, J. (2000). Global change: Rice, microbes and methane. Nature, 403, 375-377.

34. Schortemeyer, M., Hartwig, U.A., Hendrey, G.R. \& Sadowsky, M.J. (1996). Microbial community changes in the rhizospheres of white clover and perennial ryegrass exposed to free air carbon dioxide enrichment (FACE). Soil Biol. Biochem., 28, 1717-1724.

35. Seiler, W., Holzapfel-Pschorn, A., Conrad, R. \& Scharffe, D. (1984). Methane emission from rice paddies. J. Atmos. Chem., 1, 241-268.

36. Singh, J.S. (2011). Methanotrophs: the potential biological sink to mitigate the global methane load. Curr. Sci., 100 (1), 29-30.

37. Smith, J.L. \& Paul, E.A. (1990). The significance of soil microbial biomass estimates. In Soil Biochemistry. Eds. J Bollag and G Stotsky. Mercel Dekker, New York. pp. 357393.

38. Tiensing, T., Preston, S., Strachan, N. \& Paton, G.I. (2001) Soil solution extraction techniques for microbial toxicity testing: A comparative evaluation. J. Environ. Monit., 3(1), 91-96.

39. Tokida, T., Fumoto, T., Cheng, W., Matsunami, T., Adachi, M., Katayanagi, N., Matsushima, M., Okawara, Y., Nakamura, H., Okada, M., Sameshima, R. \& Hasegawa, T. (2010). Effects of free-air $\mathrm{CO}_{2}$ enrichment (FACE) and soil warming on $\mathrm{CH}_{4}$ emission from a rice paddy field: impact assessment and stoichiometric evaluation. Biogeosci., 7, 2639-2653.

40. USDA classification (1999). Soil Taxonomy: A Basic System of Soil Classification for Making and Interpreting Soil 
Rajkishore, S. K. et al. / J. Appl. \& Nat. Sci. 13 (SI), 26 - 34 (2021)

Surveys. Eds. Soil Survey Staff. United States Department of Agriculture, Agriculture Handbook 436. PP. 1-886.

41. van Bodegom, P., Stams, F., Mollema, L., Boeke, S. \& Leffelaar, P. (2001). Methane Oxidation and the Competition for Oxygen in the Rice Rhizosphere. App. Environ. Microbiol., 67(8), 3586-3597.

42. van Groenigen, K., Craig, V., Osenberg, W. \& Hungate, B.A. (2011). Increased soil emissions of potent greenhouse gases under increased atmospheric $\mathrm{CO}_{2}$. Nature, 475, 214-216.

43. van Veen, J.A., Liljeroth, E., Lekkerkerk, L.J.A. \& van de Geijn, S.C. (1991). Carbon fluxes in plant soil systems at elevated atmospheric $\mathrm{CO}_{2}$ levels. Ecol. Appl., 1, 175-181.

44. Wang, C., Jin, Y., Ji, C., Zhang, N., Song, M., Kong, D., Liu, S., Zhang, X., Liu, X., Zou, J., Li, S. \& Pan G. (2018). An additive effect of elevated atmospheric $\mathrm{CO}_{2}$ and rising temperature on methane emissions related to methanogenic community in rice paddies. Agriculture, Ecosystems and Environment, 257, 165-174.

45. Xu, Z., Zheng, X., Wang, Y., Han, S., Huang, Y., Zhu, J. \& Butterbach-Bahl, K. (2004). Effects of elevated $\mathrm{CO}_{2}$ and $\mathrm{N}$ fertilization on $\mathrm{CH} 4$ emission from paddy rice fields. Glob. Change Biol., 18, 3009.

46. Yue, J., Liang, W., Wu, J., Shi, Y. \& Huang, G. (2003). $\mathrm{CH}_{4}$ and $\mathrm{N}_{2} \mathrm{O}$ emissions from phaeozem rice field and their mitigative measures. Chin. J. Appl. Ecol., 14, 2015-2018.

47. Yue, J., Shi, Y., Zheng, X., Huang, G. \& Zhu, J. (2007). The influence of free-air $\mathrm{CO}_{2}$ enrichment on microorganisms of a paddy soil in the rice-growing season. Applied Soil Ecol., 35, 154-162.

48. Ziska, L.H., Moya, T .B., Wassmann, R., Namuco, O. S., Lantin, R.S., Aduna, J.B., Bao Jr. E.A., Bronson, K.F., Neue, H.U. \& Olszyk, D. (1998). Long-term growth at elevated carbon dioxide stimulates methane emission in tropical paddy rice. Global Change Biol., 4, 657-665. 